\title{
Building Social Capital Through Civic Education in VET: A Comparative Study of Finland and Luxembourg (1960-1970)
}

\author{
Matias Gardin
}

\begin{abstract}
Whereas social scientists and educationalists often make different assumptions about education, common to both groups is to render schooling responsible for the development of citizenship rights. Yet, a comparison of Finnish and Luxembourgian curriculum strategies in relation to building social capital - understood in the context of civic education in VET - has not been explored. Then, this study analyses these aspects during 1960-1970, for the period is regarded as the starting point for democratisation of education after WWII. The justification for the countries is based on their differences. However, both countries also experienced similar pressures to democratise education - especially regarding their VET - which need to be investigated, since little attention has been paid to the question of how the reforms of their former structures were legitimated by civic education. The conclusion addresses the importance of general education for the future of vocational careers.
\end{abstract}

Keywords • social capital, civic education, education systems, Finland, Luxembourg

\section{Introduction}

Social scientists and educationalists (including curriculum theorists) often tend to make different assumptions about education, yet common to both groups is to render schooling responsible for developing the citizenship rights. ${ }^{1}$ However, from the side of social sciences, at stake here is seldom the comparison of specific curriculum strategies in terms of building social capital - understood in the context of civic education in vocational education and training (VET) - and how this becomes associated with the wider socio-political and economic challenges of the time. Most research has tended to look at factors such as the responsibilities of citizens, formation of attitudes and identities through large-scale surveys (that is, political culture), and a number of related topics regarding civic engagement. ${ }^{2}$ But, they have also frequently failed to consider these in relation to comparative curriculum perspectives - or how political culture becomes established in the first place - which seems surprising, since especially in the beginning of modern schooling, ideas of civic education were

1 Gabriel Almond and Sidney Verba, The Civic Culture: Political Attitudes and Democracy in Five Nations (Princeton: Princeton University Press, 1963); Carole Hahn, Becoming Political: Comparative Perspectives on Citizenship Education (Albany: State University of New York Press, 1998); Robert Dahl, “A Democratic Paradox?," Political Science Quarterly 115, no. 1 (2000), 35-40.

2 Gabriel Almond, "Foreword: The Return to Political Culture," in Political Culture and Democracy in Developing Countries, ed. Larry Diamond (Boulder: Lynne Rienner, 1993), x; Christian Welzel and Ronald Inglehart, "Political Culture," in Comparative Politics, ed. Daniele Caramani (Oxford: Oxford University Press, 2011), 311-30.

Matias Gardin (PhD) is Research Associate at the Department of Education, Culture, Cognition and Society, University of Luxembourg.

Email: matias.gardin@uni.lu 
rarely seen as "educational practices sui generis" 3 but rather as the target of the entire curriculum. While social sciences has traditionally depicted democracy as the ideal political culture - defined by its "allegiant citizens" 4 - it must also be noted that the building of social capital became closely intertwined with curricular developments. It is here that comparative education, history of education, and more recently, curriculum studies/history have given new insights into the current understanding of these activities. ${ }^{5}$ As part of this, it has also become important to study the structures and transition points of education, for they constitute an integral way of understanding the larger characteristics, ideologies and political power struggles of and within the nation-state. ${ }^{6}$

Then, this study analyses these aspects in Finland and Luxembourg from 1960 to 1970 , for the period is generally regarded as the starting point for democratisation of education after the Second World War. ${ }^{7}$ In her doctoral thesis, for example, Schreiber has identified peaks in Luxembourg's curriculum history from 1839 to $1989 .{ }^{8}$ By classifying aggregation points of educational debates, she indicates precisely that in the late 1960s and early 1970s there was a sharp upsurge of educational discussions - such as those surrounding the creation of more uniform technical secondary education (Lycée technique) - and that more qualitative research on this era is warranted. ${ }^{9}$ In Finland, too, important law frames such as the Education System Act of 1968 (Laki koulujärjestelmän perusteista), led to lively public debates and political controversies, which revolutionised the country's educational landscape from the mid-1970s onwards. ${ }^{10}$ However, especially in the rapidly swelling English-speaking literature on Finland, these fundamental reforms of democratisation have not often been mentioned when the country's "educational miracle" is being explained. ${ }^{11}$

The justification for the case studies is based on their assumed key differences. Thus the Most Different Systems Designs Method (MDSD) is employed. ${ }^{12}$ As a

3 Daniel Tröhler, "Citizenship and education in a plural world," Education Letter 9, no. 2 (2014), 15.

4 Welzel and Inglehart (2011), 312-13.

5 See generally, Judith Torney-Purta et al., Citizenship and Education in Twenty-eight Countries: Civic Knowledge and Engagement at Age Fourteen (Amsterdam: IEA, 2001). For Finland, see Patricia Bromley and Elina Mäkinen, "Diversity in Civic Education: Finland in Historical and Comparative Perspective," Journal of International Cooperation in Education 14, no. 2 (2011), 35-50. For Luxembourg, see Thomas Lenz, Anne Rohstock and Catherina Schreiber, "Tomorrow Never Dies: A Socio-Historical Analysis of the Luxembourgish Curriculum," in International Handbook of Curriculum Research, ed. William Pinar (New York: Routledge, 2013), 315-28.

6 For example, see Henry Giroux and David Purpel, The Hidden Curriculum and Moral Education: Deception or Discovery? (Berkeley: McCutchan, 1983).

7 For instance, see Peter Flora and Jens Alber, "Modernization, Democratization, and the Development of Welfare States in Western Europe," in The Development of Welfare States in Europe and America, ed. Peter Flora and Arnold Heidenheimer (London: Transaction Books, 1981), 37-80.

8 Catherina Schreiber, "Curricula and the Construction of Citizens. An analysis of the Luxembourgian Curriculum in the 19th and 20th centuries" (PhD diss., University of Luxembourg, 2014), 54-65.

9 Schreiber (2014), 30-1, 277-302.

10 Matias Gardin, "Globalization in Finnish-German Educational Rhetoric, 1960-1970," in Trajectories in the Development of Modern School Systems: Between the National and the Global, ed. Daniel Tröhler and Thomas Lenz (New York: Routledge, 2015), 189.

11 See Pasi Sahlberg, "Education Reform for Raising Economic Competitiveness," Journal of Educational Change 7, no. 4 (2006), 259-87; Robin Alexander, "Moral Panic, Miracle Cures and Education Policy: what can we really learn from international comparison?," Scottish Educational Review 44, no. 1 (2012), 4-21.

12 Adam Przeworski and Henry Teune, The Logic of Comparative Social Inquiry (New York: Wiley Interscience, 1970). 
method of comparison based on dissimilarity, the merit of the research frame is that it not only allows the researcher to critically examine these issues in quite different national contexts, but also, since the coverage of education is always highly selective, it can reveal which concepts dominated civic education. It is expected that the analysis produces relevant new knowledge on civic education, and that the results increase our understanding of this study field. In this sense, Finland and Luxembourg offer an unusual comparative setting which is yet to be explored. Whereas the first has received global recognition regarding its successes in the Programme for International Student Assessment of the OECD (PISA) since 2001, the latter has generally ranked below the OECD average. ${ }^{13}$ Nevertheless, in terms of educational spending per pupil per year, Luxembourg invests considerably more than Finland: USD 21,240 and USD 16,714 respectively. ${ }^{14}$ The same is true for Luxembourgish teachers who earn more than double the salary of their Finnish counterparts: per annum starting from EUR 64,043 in Luxembourg, and EUR 30,587 in Finland. ${ }^{15}$

On a similar note, the Finnish welfare state could be classed as Nordic, ${ }^{16}$ close to what Esping-Andersen has famously referred to as the Scandinavian Social Democratic regime, ${ }^{17}$ where educational equality has traditionally been given top priority. As various authors, such as Englund, ${ }^{18}$ have shown, social policy and education are traditionally closely intertwined in this model, which means that education has generally been regarded as a citizenship right. ${ }^{19}$ More particularly, in VET, knowledge "in the widest sense" ${ }^{20}$ is normally applied in teaching as opposed to the more narrow (mainly Anglo-Saxon) tradition of training and skills stressing the role of employers. ${ }^{21}$ Perhaps not surprisingly, Ahonen and Virta stress that this has a strong value basis for the teaching of civics in Finland, related to social equality, Lutheranism, redistribution of wealth and democracy. ${ }^{22}$ Linked to this, given Finland's non-tracking comprehensive school (since 1972/7) until the age of 16 (grade 9),

13 For a cross-national comparison, see OECD, PISA 2012 Results: What Students Know and Can Do (Paris: OECD publications, 2014).

14 For Luxembourg, see OECD, "Education at a Glance 2013: Country note for Luxembourg," OECD, http://www.oecd.org/edu/Luxembourg_EAG2013\%20Country\%20Note.pdf. For Finland, see OECD, "Education at a Glance 2013: Country note for Finland," OECD, http://www.oecd.org/edu/ Finland_EAG2013\%20Country\%20Note.pdf.

15 OECD, “Teachers' salaries. Annual statutory salaries in public institutions," OECD, http://www. oecd-ilibrary.org/education/teachers-salaries-2013-1_teachsal-table-2013-1-en.

16 Pauli Kettunen, “The Nordic Welfare State in Finland," Scandinavian Journal of History 26, no. 3 (2001), 225-47.

17 Gøsta Esping-Andersen, The Three Worlds of Welfare Capitalism (Princeton: Princeton University Press, 1990), 11-12, 16-18.

18 Tomas Englund, "Education as a citizenship right-a concept in transition: Sweden related to other Western democracies and political philosophy," Journal of Curriculum Studies 26, no. 4 (1994), 38399.

19 Here is must be noted that in Sweden this has been changing since the mid-1990s. See Englund (1994), 384-87.

20 Christopher Winch, "Vocational and Civic Education: Whither British Policy?", Journal of Philosophy of Education 46, no. 4 (2012), 604.

21 Ibid.

22 Sirkka Ahonen and Arja Virta, "Toward a Dynamic View of Society: Civic Education in Finland," in Civic Education across Countries: Twenty-four National Case Studies from the IEA Civic Education Project, ed. Judith Torney-Purta, John Schwille and Jo-Ann Amadeo (Delft: Eburon Publishers, 1999), 229-56. 
this has allowed the majority of Finnish students to enter tertiary education. ${ }^{23}$ In the Catholic Grand Duchy, with its two-tier stratification after the sixth grade (age 12), the situation is often the opposite with high failure and repetition rates, and levels of inequity, which is typical of the Continental Conservative welfare state regimes, such as those found in Austria, Belgium, Germany, the Netherlands and Switzerland. ${ }^{24}$ The VET system, in turn, combines elements of the French-style full-time schooling with the German-style dual apprenticeship training. ${ }^{25}$ Education and social policy have traditionally been separated with education being linked to distinct occupational structures.

Further, the peculiar language situation in Luxembourg creates specific issues of exclusion and disadvantage for certain social strata, especially for pupils of lower socio-economic and migrant backgrounds: Luxembourgish, German and French (the three official languages) are used variedly at different levels and according to school type, ${ }^{26}$ which acts as a barrier for the non-natives whose first language is often none of the official languages. This again contrasts with Finnish schools where Finnish is the only language of instruction for all school subjects (including foreign languages), albeit Swedish has so far been recognised as the second national language of the country (and therefore not a minority language), yet just over five per cent of the population now speaks Swedish as their first language ${ }^{27}$ Historically, in Luxembourg French was traditionally the language of elite whereas the common folk spoke Luxembourgish, ${ }^{28}$ while in Finland Swedish was the language of nobility whereas the ordinary people spoke Finnish. Today, positioned strategically at the heart of Europe, Luxembourg has the highest share of non-nationals in the European Union with 44.5 per cent of the population, while in Finland, with its remote geographical location, the same figure is only 3.6 per cent. ${ }^{29}$ In primary education, for example,

23 The Finns have recently voted the comprehensive school as the greatest historical achievement of the nation, above the establishment of universal suffrage (1906), or the declaration of independence (1917). See Pilvi Torsti, Suomalaiset ja historia (Helsinki: Gaudeamus, 2012); Marjo Vilkko, Suomi on ruotsalainen (Helsinki: Schildts \& Söderströms, 2014).

24 Jutta Allmendinger and Stephan Leibfried, "Education and the welfare state: the four worlds of competence production," Journal of European Social Policy 13, no. 63 (2003), 73-74; Anne West and Rita Nikolai, "Welfare Regimes and Education Regimes: Equality of Opportunity and Expenditure in the EU (and US)," Journal of Social Policy 42, no. 3 (2013), 474-76.

25 See Lukas Graf and Daniel Tröhler, "Berufsausbildung in Luxemburg: historische Ursprünge, institutionelle Struktur und aktuelle Herausforderungen," in Bildungsbericht Luxemburg 2015 - Band 2: Analysen und Befunde, ed. Thomas Lenz et al. (Luxembourg: MENJE, 2015), 103-8.

26 With regard to language of instruction, Luxembourgish is the language used in pre-primary education while the language employed in primary education is mainly German. In secondary education, in turn, French dominates in general-academic education while German is mostly used in vocational schools.

27 Geographically, the Swedish-speaking minority is mainly concentrated in the South-Western parts of the country and archipelago where they have their own schools. In these Swedish schools the main language of instruction is Swedish, and Finnish is treated as the first national language. Conversely, Swedish in Finnish schools is compulsory from the age of 13 (grade 7), and treated as the second national language.

28 For example, see Matias Gardin and Ingrid Brühwiler, "Fabricating National Unity in Torn Contexts: World War I in the Multilingual Countries of Switzerland and Luxembourg," in Small Nations and Colonial Peripheries in World War I, ed. Gearóid Barry et al. (Leiden: Brill, 2016), 140-56.

29 European Commission, "Non-national population by group of citizenship and foreign-born population by country of birth," European Commission (Eurostat), http://ec.europa.eu/eurostat/statistics/explained/index.php/File:Non_national_population_by_group_of_citizens_andforeign-born_ population_by_country_of_birth,_1_January_2013_YB14_II.png. 
60.2 per cent of pupils now speak a language other than Luxembourgish at home. ${ }^{30}$

However, both countries also experienced similar post-war pressures to democratise education - especially in the realm of VET - which need to be investigated, since not only has little academic attention has been paid to the question of how the reforms of their educational structures were legitimated by civic education, ${ }^{31}$ but also, because VET has generally itself been studies less vis-à-vis other sectors of education, especially compared to primary and higher education. ${ }^{32}$ This study therefore deals with this one similarity in two cases which from the outset seem fundamentally different. By addressing blind spots identifiable in Finnish and Luxembourgish education literature, the following two research questions will be answered: In what ways did Luxembourg's educational structures differ from Finland when it came to those reform agendas of 1960-1970, and more specifically, how were these portrayed and justified in reference to VET? The first part of this article ("Framing social capital and education, 1960-1970") contextualises the curriculum reforms. The second part ("Education systems as expressed in civic education textbooks") compares the educational structures. The third part ("Justification of new type of VET") analyses the ways in which the reforms were interpreted and legitimated. These issues have also contemporary relevance, for the new structures these reforms produced are still largely in place today, albeit the conceptualisation of the citizen has of course altered a great deal as is evident from historical studies of educational change. ${ }^{33}$

\section{Framing social capital and education, 1960-1970}

Trust accelerates the development of democracy by encouraging people to engage in civic institutions, since this "broaden[s] the participants' sense of self, developing the 'I' into the 'we", ${ }^{34}$ as Putnam has explained it. Therefore, successful political systems have high levels of social capital, ${ }^{35}$ that is, a political culture of trust and co-operation which makes collective action effective. Conversely, distrust results in a downfall of political culture, which reduces the effectiveness of political systems. In this context, it has now also become commonplace to link social capital to education, and more recently, to ask where social capital and political culture come from in the first place. ${ }^{36}$ Education is here seen as the very method of transmitting and reproducing dominant values from the nation-state to its citizenry, and thereby, social structures and practices are viewed as being also intrinsically conditioned by public education.

Further, since the mid-1970s at least, curriculum theorists have addressed the

30 MENJE, Les chiffres clés de l'Éducation nationale. Statistiques et indicateurs 2012-2013 (Luxembourg: MENJE, 2014).

31 The term civic education here refers explicitly to the school subject civics, that is, yhteiskuntaoppi and Bürgerkunde.

32 For example, see Graf and Tröhler (2015), 103-8.

33 For example, see Englund (1994), 383-84; Cf. Winch (2012), $605 f$.

34 Robert Putnam, “Bowling Alone: America's Declining Social Capital," Journal of Democracy 6, no. 1 (1995), 67.

35 For a discussion, revision and critique on the concept of social capital, and its different forms, see James Coleman, "Social Capital in the Creation of Human Capital," The American Journal of Sociology 94, supplement: Organizations and Institutions: Sociological and Economic Approaches to the Analysis of Social Structure (1988), 95-120.

36 See Rod Hague and Martin Harrop, Comparative Government and Politics (London: Macmillan, 2013), 93-111. 
importance of curricular activities on the wider development of society, and how the curriculum structures the nation-state and vice versa. ${ }^{37}$ For example, by claiming that "textbooks contain an expression of the self-image of the nation-state" 38 that pupils learn in the course of schooling, Fuchs and Otto aptly assert that:

Schools as institutions, and the educational media they make use of, carry out a central function in debates conducted within societies and the academic arena. Schools and educational media have an authoritative role in the transmission of knowledge that is deemed socially relevant; they are likewise creators of meaning, that is, they appropriate and transmit history in the context of the present and future, progressing from the contemporary here and now. ${ }^{39}$

In other words, since textbooks were usually approved by some form of a state apparatus, often ministries of education or their subordinates, their contents were also deeply embedded in the national frame..$^{40}$ They thus directly mirrored what was (or what was not) important and desirable in a society. "They reflect the interests, ideologies, scenarios, dreams, plans and orientations of the political decision-making organs of the state," ${ }^{41}$ Rinne argues, "They represent, in effect, the collective will of the nation to educate and socialize the generations to come. In this collective will, of course, the political and cultural power relations and interests are also seen." ${ }^{42}$

When analysed against the background of socio-economic development of the late 1960s and early 1970s, Finland and Luxembourg offer an interesting comparative setting for Putnam's understanding of social capital linked to Fuchs and Otto's national relevance of educational media. It is no surprise that educational reforms were often presented and legitimised by making references to national cohesion, trust and effective nation-building, as methods to boost social capital. In technical secondary education, particularly, the aim was also to improve the general perception of vocational training to avoid early schooling leaving dropouts, and to make its image more attractive by highlighting the importance of generic skills as opposed to career specificities, which had been more the case in the past. As the ministries of education attempted to influence political culture via schooling, civic education also reflected the post-war changes in and challenges for statehood, power and citizenship; the aim also being political integration at the time of rising globalisation. ${ }^{43}$

In the optimistic 1960s, the rise in social capital went hand in hand with wider

37 For example, see Ivor Goodson, The Making of the Curriculum: Collected Essays (Washington DC/ London: Falmer Press, 1988), 24-37.

38 Eckhardt Fuchs and Marcus Otto, "Introduction: Educational Media, Textbooks, and Postcolonial Relocations of Memory Politics," Journal of Educational Media, Memory, and Society 5, no. 1, Special Issue: Europe in Postcolonial Politics of Memory in Educational Media (2013), 2.

39 Fuchs and Otto (2013), 2-3.

40 Although textbooks are often no longer approved by ministries of education, it can still be argued that they are part of the ideological control of education as their writers have to adjust to the curricula.

41 Risto Rinne, "From ethos to habitus: the changing curriculum codes of Finnish Schooling, 1881-1985," Journal of Curriculum Studies 20, no. 5 (1988), 443.

42 Rinne (1988), 443.

43 See Alan Reid et al. eds., Globalization, the Nation-State and the Citizen: Dilemmas and Directions for Civics and Citizenship Education (New York: Routledge, 2010); Gardin (2015), 183-96. 
socio-economic developments. Set against economic changes, demographic pressures and shifting occupational structures of 1960-1970, the Zeitgeist demanded increased educational investments. For example, in 1960 there were 48,379 pupils in Luxembourg's compulsory education system, whereas in 1970 the number had risen to 62,036 , indicating an increase of 22 per cent in 10 years. ${ }^{44}$ In Finland, too, in 1960 only 38 per cent of pupils continued their studies after elementary levels, whereas in 1970 the figure was 59 per cent ${ }^{45}$ implying an almost identical growth level to that of Luxembourg. As an answer to these challenges, both countries introduced legislation that was aimed for the improvement of social capital in the sphere of VET, which had previously been a neglected target group. In Luxembourg this was done by unifying technical secondary education in 1979 (implemented during the 1980s), ${ }^{46}$ and in Finland by changing the entire system to comprehensive schooling in 1968 (implemented during the 1970s). ${ }^{47}$ Yet, to compare Finland and Luxembourg in a sufficient way, a closer look at the countries' education systems around the years 1970 and 1979, that is, before and after these major reforms took place, becomes necessary. Then, how did civic education textbooks portray VET as part of the overall educational structure? How did they legitimate reform?

\section{Education systems as expressed in civic education textbooks}

It was in this expansionist and reformist framework that Ragnar Meinander's Suomalainen yhteiskuntamme ("Our Finnish society") was first published in 1955 (see figure 1). ${ }^{48} \mathrm{He}$ had written the original work in Swedish under the title Samhället vi lever $i$ ("The society we live in"). Published by Otava, one of the leading Finnish publishing houses, the textbook was translated into Finnish by Olavi Kostia. It had seven editions in total. The last one was released in 1967, thus making it one of the most established school books in the study of civics. ${ }^{49}$ Of course, alongside there were other textbooks which targeted different school types. To take an example, in the middle school (keskikoulu) one of the main civics textbook was Yhteiskuntaoppi ("Civics") by Veikko Huttunen and Kai Lehtonen, which had eight editions between 1962 and $1973 .{ }^{50}$ However, it is interesting to note that no similar textbook explicitly existed for the upper secondary school (lukio). Suomalainen yhteiskuntamme, with 256 pages, was approved by the Finnish National Board of Schooling (kouluhallitus),

44 Paul Reiff, "Lévolution de l'enseignement depuis 1960," STATEC, http://www.statistiques.public.lu/ fr/publications/series/luxembourg/2012/14-12/index.html.

45 Sari Pekkala Kerr, "Koulutusmenot ja väestön koulutustaso," in Tiedon ja osaamisen Suomi. Kasvatus ja koulutus Suomessa 1960-luvulta 2000-luvulle, ed. Pauli Kettunen and Hannu Simola (Hämeenlinna: Karisto, 2012), 297.

46 See Chambre des Députés, "Loi du 21 mai 1979 portant organisation de la formation professionnelle et de l'enseignement secondaire technique," Chambre des Députés, http://www.legilux.public.lu/ leg/a/archives/1979/0041/a041.pdf.

47 See Eduskunta, Hallituksen Esitys Eduskunnalle Laiksi Koulujärjestelmän Perusteista: He44/1967 (Helsinki: Valtion Painatuskeskus: asetuskokoelma 467, 1968).

48 Ragnar Meinander, Suomalainen yhteiskuntamme (Helsinki: Otava, 1967).

49 Secondary literature also mentions the textbook linked to the author. For example, see Pentti Huovinen, Kuka kukin on 1978: Henkilötietoja nykypolven suomalaisista (Helsinki: Otava, 1978), 585.

50 Veikko Huttunen and Kai Lehtonen, Yhteiskuntaoppi (Helsinki: WSOY, 1970). See also, Pauli Arola, "Oppikoulun yhteiskuntaopista peruskoulun yhteiskuntatiedon oppikirjaksi," in Oppikirjat oman aikansa ilmentyminä, ed. Jouko Kauranne (Helsinki: Suomen kasvatuksen ja koulutuksen historian seura, 2014), 217-33. 
renamed as the Finnish National Board of Education (opetushallitus) in 1991, which was (and is) responsible for the development of national education at most levels. It remained subordinate to the Finnish Ministry of Education and Culture (Opetus- ja kulttuuriministeriö, or OKM).

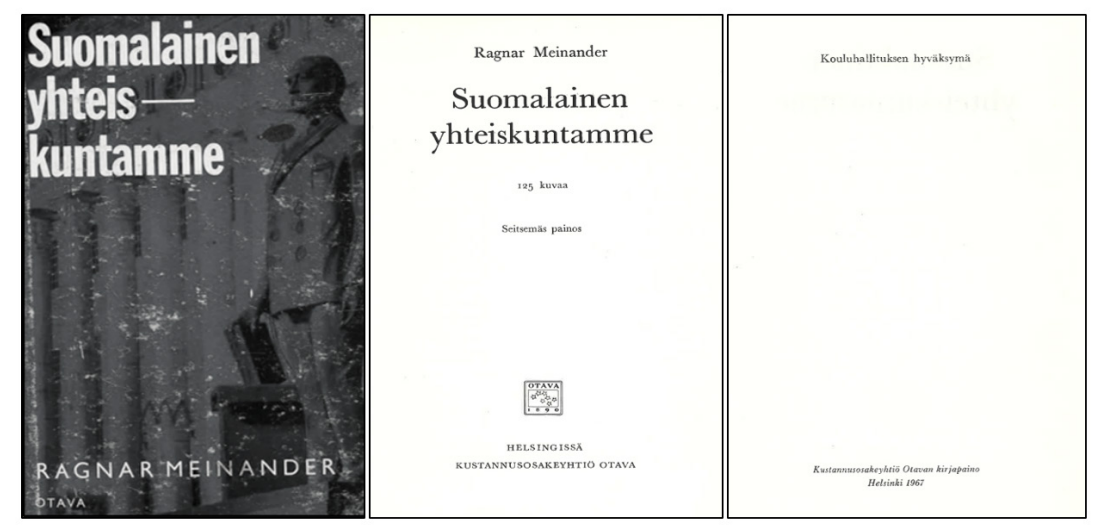

Figure 1. Suomalainen yhteiskuntamme

The author, Meinander, was a Swedish-speaking Finn working as a government counsellor (hallitusneuvos), a senior position he held within the OKM. Aimed primarily for pupils in technical high schools (ammattikoulu), his work was above all a civic education textbook, but it also included general history of Finland, together with issues dealing with governance. It was also stated in the introduction that "All citizens should at least have an overall picture of the structure of society and its activities." 51 Thus, the book could be used freely in the so-called "popular education" (kansansivistys): "Responsibility for taking care of societal matters belongs to all of us, and the answer to social issues is reflected in our daily lives in a way that it cannot be indifferent to anyone how they are treated." ${ }^{2}$ The table of contents lists 16 main sections. The first part dealt with the system of government, citizen's rights and responsibilities, political parties, legal matters, and the role of state. The second part contained religious concerns, taxation, communal sovereignty, and culture and vocational education. The final part consisted of policing, business and economics, employer-employee relations, and foreign affairs. Since this study mainly deals with education's conjuncture with social capital, from here onwards I will mostly concentrate on the part dealing with "Culture and vocational education" (Henkinen sivistys ja ammattikasvatus)..$^{53}$

In Luxembourg, in turn, given its stratified schooling structure after the sixth grade (age 12), also civic education textbooks were thereafter strictly divided ac-

51 Meinander (1967), 5. "Kaikilla kansalaisilla tulisi olla ainakin yleinen kuva yhteiskunnan rakenteesta ja toiminnasta." All translations from Finnish, French and German in this article are the author's.

52 Meinander (1967), 5. "Vastuu yhteiskuntamme asioiden hoidossa kuuluu meille kaikille, ja yhteiskunnallisten kysymysten ratkaisu heijastuu meidän jokapäiväiseen elämäämme siten, ettei voi olla kenellekään yhdentekevää, miten niitä hoidetaan."

53 Meinander (1967), 135-50. 
cording to four different school types. ${ }^{54}$ In technical secondary education, one of the major works was Lehrbuch der Bürgerkunde: für die technischen und beruflichen Lehranstalten ("Citizenship Textbook: for technical and vocational schools"). ${ }^{55}$ It was written by Jean Jaans, Pierre Kirchen, Marcel Spielmann and Jacques Wathgen, who were all established scholars and educationalists in Luxembourg (see figure 2). Together and separately, they contributed to a large number of Luxembourgish textbooks in civic studies at technical secondary levels. The textbook was first published in 1970, and, like Suomalainen yhteiskuntamme in Finland, it had seven editions thus making the book one of the most recognised works in the study of civics in the country, as also acknowledged by secondary literature. ${ }^{56}$

Also similar to Finland, it is noteworthy to mention that in the general-academic track (Lycée général) no similar textbook existed. The final volume was released ten years later, and thereafter updated versions appeared under new names. With 336 pages, the book was meant as a civics textbook but it was also viewed as a manual for public law. The following citation linking democracy, citizens' duties and education, by German trade unionist Ludwig Rosenberg, was to guide the reader throughout the textbook: "All deficiencies and errors of democracy can only leave us to do more and more, to educate people to become aware of their duties as democrats, and to fully use the numerous possibilities given to them." ${ }^{77}$ The Lehrbuch was published by Genossenschaftsdruckerei, the forerunner of the leftist Editpress, and approved by Luxembourg's Ministry of National Education (Ministère de l'Éducation nationale, or MEN), which, similar to Finland, was and is responsible for public education at most levels. ${ }^{58}$ The seven main sections were titled: living in a state, international institutions, vocational training, labour law, social insurance, family legislation, and introduction to civil law. Again, since the focus of this study is on education and social capital, I will hereafter mainly concentrate on the section titled "Vocational training" (Berufsausbildung)..$^{59}$

54 In middle schools, for example, one of the books was Internationale Einrichtungen: Kursus für die Sekunda der Mittelschulen ("International institutions: course for the second-year pupils of middle schools") by Victor Diederich. Regarding complementary classes, one of the major works was Sozialkunde: Handbuch für die Komplementarklassen (8. Schuljahr) des Grossherzogtums Luxemburg ("Social studies: handbook for complementary classes (8th grade) of the Grand Duchy of Luxembourg") by Victor Diederich and Marcel Ditsch.

55 Jean Jaans et al., Lehrbuch der Bürgerkunde: für die technischen und beruflichen Lehranstalten (Esch-sur-Alzette: Genossenschaftsdruckerei, 1970).

56 For example, see Emile Thoma, Le livre scolaire luxembourgeois à travers les âges (Luxembourg: Bibliothèque nationale, 1980), 107.

57 Jaans et al. (1970), 17. “Alle Mängel und Fehler der Demokratie können uns nur verlassen, mehr und immer mehr zu tun, um die Menschen zu erziehen, sich als Demokraten ihrer Aufgaben bewußt zu werden und die ihnen reichlich gegebenen Möglichkeiten auch wirklich zu nutzen."

58 In Luxembourg, the MEN often closely co-operated with other ministries, and its head, the National Education Minister (Ministre de l'Éducation nationale), could also lead other ministries.

59 Jaans et al. (1970), 137-62. 


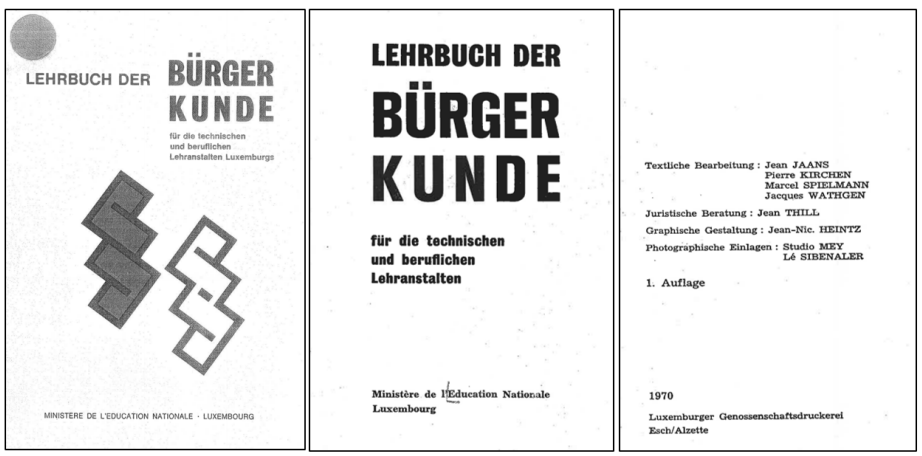

Figure 2. Lehrbuch der Bürgerkunde: für die technischen und beruflichen Lehranstalten

As indicated under this section, Luxembourg's education system in 1970 consisted of a four-tier tracking structure after the sixth school year. After the common primary school (Primärschule, ages 6-11), pupils were divided into the following streams: general secondary school (Lycée général, ages 12-18), middle school (Mittelschule, ages 12-16), vocational school (Berufsschule, ages 12-16), and complementary classes (Komplementarklassen, ages 12-15). Compulsory education ended at the age of 15 .

Finland's system, in turn, explained under the equivalent section dealing with education, was similarly made up of a six-year elementary school (kansakoulu, ages 7-12), after which most pupils would apply and go to middle schools (keskikoulu, ages $12-16),{ }^{60}$ or to secondary general schools (kansalaiskoulu, ages $\left.13-15\right)$. Nevertheless, there was also a "track" called the grammar school (oppikoulu) from the fourth year of elementary school onwards. Often a private institution, it had strict entrance examinations and annual fees. ${ }^{61}$ Oppikoulu was often seen as the direct path to upper secondary education (and therefore to universities). At the age of 16 pupils could further choose between vocational schools (ammattikoulut, ages 16-19), ${ }^{62}$ and upper secondary schools (lukiot, ages 16-19). ${ }^{63}$ Like in Luxembourg, compulsory education ended at the age of 15 . Also, because children started schooling a year earlier, and partly because vocational schools normally ended at the age of 16 , if not earlier, the young Luxembourgers finished their public education few years earlier on average than their counterparts in Finland.

In structural terms, a major dividing line between Finland and Luxembourg was of course the fact that pupils in Luxembourg began their vocational education track already at the age of 12 (grade 7), as opposed to Finland where this was normally 16 (grade 10). ${ }^{64}$ Another difference was that pupils from the Finnish keskikoulu could

60 This school type was also sometimes referred to as the lower level of grammar school (oppikoulu). This naming depended on the overall structure of the institution in question. Some middle schools (mainly in larger cities) included lower and upper levels, while others (mainly in the countryside) only had a lower level.

61 Some pupils who showed exceptional talent were exempt from paying fees. This non-fee paying status (vapaaoppilas), however, depended on the earnings of the parents.

62 Here, the term ammattikoulu is used as an umbrella term for all second-level vocational institutions, including general vocational schools (yleiset ammattikoulut), commercial schools (kauppakoulut) and colleges (opistot).

63 This school type was also referred to as the upper level of grammar school.

64 There were some colleges that pupils entered directly after the elementary school, but their share was marginal. 
further apply to lukio, that is, the upper level of oppikoulu, and this was in effect a very common practice. In 1970, for example, approximately 60 per cent of pupils from keskikoulu continued their studies in lukio. ${ }^{65}$ In Luxembourg, by contrast, pupils who had entered Berufsschule or Mittelschule very rarely found themselves in the upper levels of Lycée général later on in their educational paths. Therefore, early and strict separation lines after elementary levels characterised the education system in Luxembourg, whereas the Finnish structure could be interpreted as having been more flexible.

Yet, here it must be mentioned that oppikoulu (very much like the Lycée général in Luxembourg) was considered superior to the other tracks because of its more theoretical curriculum, and that high levels of educational inequality characterised this relationship with regard to the quality of teaching practice. In addition, many parents of lower socio-economic backgrounds (or those living in more remote geographical locations) could not afford to put their children into oppikoulu. A major issue in both countries was also related to the tracks Komplementarklassen and kansalaiskoulu, which were often seen as dead-ends in the educational ladder. ${ }^{66}$ Loosely comparable to the German idea of general schools (Hauptschule), after completion at the end of compulsory education, most pupils did not continue their studies in upper secondary institutions and thus left education at an early age, although further vocational study was being encouraged.

In Finland, the Education System Act of 1968 revolutionised the country's former system from a stratified towards a unified structure and curriculum. The new comprehensive school (peruskoulu) now replaced oppikoulu, keskikoulu and kansalaiskoulu. Upper secondary education was left in place, but compulsory education was extended until the age of 16 (grade 9). Following largely the Swedish schooling example from 1962, this was a milestone in the country's curriculum history. Implementation commenced in 1972 and progressed from north to south. The stratified system was fully abolished in 1977 when the southern regions of Espoo, Helsinki, Kauniainen and Vantaa opted for the new comprehensive school.

In Luxembourg, a decade later, a similar reform agenda took place regarding the creation of uniform technical secondary education by the law of 21 May $1979 .{ }^{67}$ This unified, albeit loosely, all the former middle schools and vocational institutions under the header Lycée technique, but very different from Finland, left the Komplementarklassen and Lycée général in place. ${ }^{68}$ It is also worth mentioning that compulsory education had already been extended to nine years by the law of 5 August $1963 .{ }^{69}$

Therefore, after 1979, the differences between Luxembourg and Finland became more pronounced for two reasons. First, while Finland abolished kansalaiskoulu

65 Huttunen and Lehtonen (1962), 96.

66 For Luxembourg, see École et vie, “Die Komplementarklassen im Gespräch,” École et vie 3 (Luxembourg: Syndicat national des enseignants, 1975), 62-76. For Finland, see Matias Gardin, "States of education: reflections on the relationship between welfare state and education in Finland and the Federal Republic of Germany 1960-1970" (PhD diss., King’s College London, 2013), 7.

67 Chambre des Députés (1979).

68 Lycée général and Lycée technique were also referred to as École secondaire or École secondaire technique, or both as post-primary education (Enseignement postprimaire).

69 Chambre des Députés, "Loi du 5 août 1963 portant réforme de l'éducation préscolaire et de l'enseignement primaire," Chambre des Députés, http://www.legilux.public.lu/leg/a/archives/1963/0047/ a047.pdf. 
gradually from 1972 to 1977, Luxembourg's Komplementarklassen were only absorbed by Lycée technique starting from 1994 (by the law of June 3 1994), ${ }^{70}$ in which they became known as a preparatory stream (Régime préparatoire). Second, because all the former lines in compulsory education were replaced by peruskoulu in Finland, this also meant that now all pupils would spend the nine compulsory school years together in the same institution. In the new comprehensive school there were no entrance examinations or fees. Nor were there strict streams based on academic performance. ${ }^{71}$ The privately owned institutions were taken over by local municipalities. In Luxembourg, by contrast, even the lower levels of Lycée général and Lycée technique were by no means uniform entities, but they included numerous different professional, technical and academic tracks, each with their own entrance examinations and curricular specifications. ${ }^{72}$ Then, compared to Finland: high social stratification, fragmented curricula, and academic selectiveness from an early age characterised the Luxembourgian system even after 1979.

\section{Justification of new type of VET}

This article now proceeds to investigate how the new above mentioned structures of education, VET particularly, were justified in the civics textbooks, and how the future reforms (in Luxembourg after 1979, and in Finland after 1968) were dealt with respectively. It is perhaps no surprise that in the Finnish textbook, the new system was to be better understood against the background of the former (less equal) two-fold structure that "had to be" reformed, which is clearly advocated in Meinander's writings. Linked to this, more importantly, it was stressed that the coming of the comprehensive school would mean that the future students in vocational high schools would have exactly the same background education behind them as those aiming for lukio education. To educate all pupils as broadly as possibly was seen as the new security requirement, serving the changing needs of post-war societies, ${ }^{73}$ which was in line with the general characteristics of VET in the Nordic countries (or the Social Democratic welfare state regimes), in comparison to, for example, the United Kingdom. ${ }^{74}$

The acute need for a fundamental change was simultaneously expressed in the negative depictions of overcrowded grammar schools and their selectiveness, and their concomitant exclusive settings for the working classes and rural populations, ${ }^{75}$ that is, groups that had traditionally dominated the vocational sector. By insisting that the most important function of education was personality development, the author went to claim that future generations could no longer afford school dropouts,

70 Chambre des Députés, "Loi du 3 juin 1994 portant création du régime préparatoire de l’enseignement secondaire technique," Chambre des Députés, http://www.legilux.public.lu/rgl/1994/A/1068/1.pdf.

71 In some schools, a system of tracking students in certain subjects, such as mathematics, remained during the initial phase of implementation. This type of tracking system (tasokurssit) was formally abolished in 1985 .

72 Schreiber (2014), 50.

73 Meinander (1967), 135-43.

74 See Winch (2012), 613-7. In the Liberal welfare state regimes, such as those found in the United Kingdom and United States, the VET sector tends to be employer-dominated and therefore rudimentary.

75 Meinander (1967), 139-42. 
because of their social and economic costs, and that the level of general education must be increased for those who aim for vocational careers:

The provision of certain general education plays a significant role in this. In-depth education heightens one's personality. And if the entire nation has the chance to become part of this education to the greatest extent, its intellectual power will grow, and for its part, its ability to make something creative for itself and the whole humanity will increase. [...] As the need for people who have specialised training rises in society, an individual has to acquire good education, in order for one to stick up for him- or herself in the struggle for existence, and to safeguard his or her future. ${ }^{76}$

Nevertheless, in this context the Finnish term sivistys seemed more comparable to the German idea of Bildung (self-cultivation, spiritual and cultural development) than the English equivalent or translation of education. In the textbook, sivistys (civilisation, general education, culture) was used in a very specific way. In effect, although a distinction was explicitly made between general education (yleissivistys) and professionalised education (ammattisivistys), it was simultaneously argued that these two should be integrated much closer in the future. As Meinander's above statement implies, they were employed to demonstrate that education should play a central function in the growth of one's personality and self-esteem. The building of social capital, in turn, depended on the positive contribution the nation's future citizens were to play in the formation of effective political culture. In concrete terms, especially in reference to VET, civic education should buffer against technological transformation and increasing international competition in the Cold War framework, against uncertain future and the formation of a demoralised societal underclass in Finland. The Darwinian term "struggle for existence" (olemassaolotaistelu) further pointed to the changing nature of education; its competiveness and comprehensiveness. More educated citizens would be better equipped to deal with rapid socio-economic change, and face the structural challenges of tomorrow, which were particularly evident in VET, given the changed socio-economic structure of society and as a result, the uncertainty of many vocational-level careers.

In Luxembourg, too, it was recognised that general training was needed more, and there was an attempt to transcend the former boundaries between the different types of education, albeit the textbook did also distinguish between Allgemeinbildung (in Lycée général) and new Berufsausbildung (in Berufsschulen, later absorbed by Lycée technique). ${ }^{77}$ The former structures, however, were not criticised as such but it was pointed out that many vocational occupations would simply disappear in the future, hence the need for more generic education at all levels. ${ }^{78}$ Instead of this being addressed as part of one's personality development like in Finland, general education was linked to working life, duty and job satisfaction, which gains a dominant meaning here:

$\overline{76 \text { Meinander (1967) }}$, 135. “Tietyn yleissivistyksen antamisella on siinä merkittävä osuus. Syvällinen sivistys kohottaa yksilön persoonallisuutta. Ja jos koko kansa pääsee mahdollisimman suuressa määrin sivistyksestä osalliseksi, kasvaa sen henkinen voima ja kyky suorittaa omalta osaltaan jotakin luovaa itsensä ja koko ihmiskunnan hyväksi. [...] Sitä mukaa kuin erityiskoulutuksen saaneitten tarve yhteiskunnassa kasvaa, on yksityisen pakko hankkia itselleen hyvä koulutus, jos hän aikoo pitää puoliaan olemassaolotaistelussa ja turvata tulevaisuutensa."

77 Jaans et al. (1970), 137-62.

78 Jaans et al. (1970), 137-62. 
Not only is work useful for earning one's living; it gives us, when we understand it properly, also a deep inner satisfaction [...]. Therefore, our work force is our most prized asset; to train, utilise and maintain it properly is the first duty towards ourselves and our fellow men. Those who do not do this, deceive themselves as for one's purpose in life, and steal from others. ${ }^{79}$

Put differently, and similar to the Finnish case at a more generic level, it was argued that for if one is not able to execute his/her personality and talent in the education system (and later in the labour market), this would somehow mean living to the side of one's citizenship - at the edge of one's national identification and civic obligations - further cementing one's "marginalised" or "disadvantaged" position in society. Especially in Luxembourg, given the country's rising immigration levels and the problems associated with the multiple languages of instruction for the non-natives - a situation which was largely absent in Finland - this was remarkable because the completion rates in VET barely exceeded 60 per cent, and grade repetition remained a very common practice. ${ }^{80}$

To hinder pupils leaving education at an early age, and comparable to Finland's "character building mission", the normative aim was also to try to explain that those without heightened generic educational backgrounds would instantly lose in the international skills competition of the future, which would have a negative effect on the political culture of the country, and by that, on the building of social capital. ${ }^{81}$ By stressing "abstract citizenship", this is precisely what Dahrendorf also repeatedly warned against in his well-known Bildung ist Bürgerrecht:

Legal equality remains indeed fiction, if people are unable, due to their social ties and obligations, to make use of their rights. Those who are permitted to send their children to higher level schools, but fail to consider this because of their social situation - for example as Catholics, blue-collar workers or villagers - are very abstract citizens, citizens of theory, but not of reality. ${ }^{82}$

In short, the authors in Finland and Luxembourg wanted to make pupils at technical secondary levels conscious of the countries' education systems, and clarify the new role of VET, especially its increasing and necessary future ties to general education - albeit in the Finnish case this type of focus was more explicit. The idea was to blur the distinction between yleissivistys and ammattikoulutus, Bildung and Ausbildung, by encouraging greater civic engagement. In other words, the future educational re-

79 Jaans et al. (1970), 137. "Die Arbeit ist aber nicht nur wegen des Verdienstes nützlich; sie gibt uns, wenn wir sie richtig auffassen, auch eine tiefe innere Befriedigung [...]. Deshalb ist unsere Arbeitskraft unser wertvollster Besitz; sie auszubilden, richtig anzuwenden und zu erhalten ist es erste Pflicht gegen uns und unsere Mitmenschen. Wer dies nicht tut, betrügt sich selbst um seinen Lebensinhalt und bestiehlt die andern."

80 OECD, OECD Economic Surveys Luxembourg (Paris: OECD publications, 2015), 39.

81 Jaans et al. (1970), 137-38.

82 Ralf Dahrendorf, Bildung ist Bürgerrecht: Plädoyer für eine aktive Bildungspolitik (Hamburg: Nannen-Verlag, 1965), 24. "Rechtliche Chancengleichheit bleibt ja eine Fiktion, wenn Menschen auf Grund ihrer sozialen Verflechtungen und Verpflichtungen nicht in der Lage sind, von ihren Rechten Gebrauch zu machen. Wer seine Kinder zwar auf die höhere Schule schicken darf, aber durch seine soziale Lage - als Katholik etwa, oder als Arbeiter, als Dorfbewohner - gar nicht auf den Gedanken kommt, dies auch zu tun, ist ein sehr abstrakter Staatsbürger, ein Staatsbürger der Theorie, doch nicht der Realität.” 
forms were interpreted as part of the change in the post-WWII welfare state: there was an imperative to take learning seriously, and value education as one's foundation in life. Hence, by highlighting the increased general education levels for those studying for technical careers, and the concomitant social capital this would generate, future schooling was addressed as a unifying experience, a part of one's citizenship, instead of a separation line.

\section{Conclusion}

In today's Luxembourg, those who enter the vocational education track represent 47 per cent of all secondary school pupils, while 35.3 per cent choose general-academic education. ${ }^{83}$ Although it has been the constant aim of different Luxembourgish governments as decision-makers, and various ministries of education as their executors, to increase the number of those studying in Lycée général, and to avoid high failure and repetition rates in education generally, vocational training has largely maintained its popularity amongst the Luxembourgish pupils. Also in Finland, roughly 45 per cent choose the vocational education track today, and recently vocational institutions have again become more popular than upper secondary schools. ${ }^{84}$ To make vocational training a more attractive career path during the post-war years, and to encourage trust, co-operation and civic engagement this way, has clearly been a success story, especially when compared to the Anglo-Saxon countries, where VET has largely remained underdeveloped vis-à-vis general academic education/higher education. ${ }^{85}$

Keeping this in mind, it is important to note that the textbooks examined in this article dealt at length with education, thus demonstrating its increased importance and authority for building much needed social capital against the socio-political and economic pressures of 1960-1970. By forming a part of the wider democratisation literature, and by offering a comparative study of two education systems, this study has dealt with these books as a useful way of understanding one of the curriculum strategies that the authors, under the surveillance of their respective ministries of education, employed to influence political culture. In other words, by detecting similarities and differences in the making of citizens in modern European societies, this analysis has pointed to one of the methods of how social capital becomes established in the first place, which has been an under-researched study area, particularly in the field of social sciences.

With regard to education and Putnam's understanding of social capital, the greatest difference among the Finnish and Luxembourgish textbooks could be seen in the style they refer to the concept of general education. Understandably, in Finland the old system was heavily criticised whereas the Luxembourgish authors wanted to justify the new status quo rather than criticise the older fragmented system. Regarding the creation of Lycée technique in Luxembourg, general education was addressed in relation to working life and moral duty towards the fellow citizens, whereas in the

83 Séverine Goffin, "Lorientation des élèves changera dès 2016," Lessentiel, http://www.lessentiel.lu/fr/ news/story/18931211.

84 Marjo Valtavaara, "Lukioon entistä vaikeampi päästä - ylioppilaiden määrä on romahtanut," Helsingin Sanomat, http://www.hs.fi/kotimaa/a1418970101442.

85 Winch (2012), 603-5. 
case of peruskoulu in Finland, individualism and personality development were highlighted in the same context. As creators of the new meaning attached to VET, both civic books aimed for similar goals but used different methods to justify change. This type of rhetoric surrounding the post-WWII democratisation of education paved the way towards life-long learning and skills development, risk investment society, international competitiveness and second-chance education; concepts which were exemplified and mainstreamed in the works of Anthony Giddens, Ben Levin, Pasi Sahlberg, Roger Dale, Scott Lash and Ulrich Beck two or three decades later.

As for VET structures, especially regarding the justification of their reform, I have shown how Finland and Luxembourg - despite their fundamental differences at a more general level - pushed for similar citizenship training by laying stress on more general education for vocational-level pupils. There was an attempt to avoid early school leaving dropouts (and its many-faceted social problems and economic costs), to overcome socio-economic exclusion and civic disengagement, and thereby, to make technical secondary education more popular among the young Finns and Luxembourgers. The textbooks also had an interesting authoritative function, for in Finland the term kansalaiskasvatus was used specifically for pupils in technical secondary schools in order to encourage higher civic participation, while in Luxembourg the notion of Berufsausbildung carried a similar connotation. These were the concepts that were used to educate the future citizens, but only those who had entered the vocational tracks in the education system, for in the Finnish lukio or Luxembourgish Lycée général no similar civics textbook existed. What this of course implies is that pupils at general-academic levels needed different type of understanding of civics than those in vocational schools. In this sense, if these textbooks are indeed deemed "socially relevant" 86 by viewing them as Fuchs and Otto's "expression of the self-image of the nation-state", ${ }^{87}$ or if schooling as such is rendered responsible for developing the citizenship rights of a civil society, we must bear in mind that for different groups the concept of "civics" also meant, or it should have meant at least, quite different things. It is here that the curriculum - understood in the context of citizenship education and educational structures - can offer us a more nuanced and sophisticated understanding of political culture.

In short, political culture and social capital had to be created. This was also done through educating the citizens for the uncertain future, given the rapid change in the economic structure of society, and as its effect, the unpredictable tomorrow of many vocational careers. Tighter link between citizens and state institutions was fostered as a vaccination against societal exclusion. Spreading the message of more effective citizenship via civic education, and thus more efficient political system, new norms and cultural expectations were set for VET: to maximise its role in building social capital, to influence political culture, and to authorise and redefine its new position in the education system. Viewed in this light, textbooks provide a valuable resource for researchers interested in the national relevance of educational change.

86 Fuchs and Otto (2013), 2.

87 Fuchs and Otto (2013), 2-3. 


\section{References}

Ahonen, Sirkka, and Arja Virta. "Toward a Dynamic View of Society: Civic Education in Finland." In Civic Education across Countries: Twenty-four National Case Studies from the IEA Civic Education Project, edited by Judith Torney-Purta, John Schwille, and Jo-Ann Amadeo, 229-56. Delft: Eburon Publishers, 1999.

Alexander, Robin. "Moral Panic, Miracle Cures and Education Policy: what can we really learn from international comparison?" Scottish Educational Review 44, no. 1 (2012), 4-21.

Allmendinger, Jutta, and Stephan Leibfried. "Education and the welfare state: the four worlds of competence production." Journal of European Social Policy 13, no. 63 (2003), 73-4.

Almond, Gabriel. "Foreword: The Return to Political Culture." In Political Culture and Democracy in Developing Countries, edited by Larry Diamond, x. Boulder: Lynne Rienner, 1993.

Almond, Gabriel, and Sidney Verba. The Civic Culture: Political Attitudes and Democracy in Five Nations. Princeton: Princeton University Press, 1963.

Arola, Pauli. "Oppikoulun yhteiskuntaopista peruskoulun yhteiskuntatiedon oppikirjaksi." In Oppikirjat oman aikansa ilmentyminä, edited by Jouko Kauranne, 217-33. Helsinki: Suomen kasvatuksen ja koulutuksen historian seura, 2014.

Bromley, Patricia, and Elina Mäkinen. "Diversity in Civic Education: Finland in Historical and Comparative Perspective." Journal of International Cooperation in Education 14, no. 2 (2011), 35-50.

Chambre des Députés. "Loi du 5 août 1963 portant réforme de l'éducation préscolaire et de l'enseignement primaire." Chambre des Députés. http://www.legilux. public.lu/leg/a/archives/1963/0047/a047.pdf (accessed June 1, 2015).

Chambre des Députés. "Loi du 21 mai 1979 portant organisation de la formation professionnelle et de l'enseignement secondaire technique." Chambre des Députés. http://www.legilux.public.lu/leg/a/archives/1979/0041/a041.pdf (accessed July 15, 2015).

Chambre des Députés. "Loi du 3 juin 1994 portant création du régime préparatoire de l'enseignement secondaire technique." Chambre des Députés. http://www.legilux.public.lu/rgl/1994/A/1068/1.pdf (accessed September 20, 2015).

Coleman, James. "Social Capital in the Creation of Human Capital." The American Journal of Sociology 94, supplement: Organizations and Institutions: Sociological and Economic Approaches to the Analysis of Social Structure (1988), 95-120.

Dahl, Robert. “A Democratic Paradox?” Political Science Quarterly 115, no. 1 (2000), 35-40.

Dahrendorf, Ralf. Bildung ist Bürgerrecht: Plädoyer für eine aktive Bildungspolitik. Hamburg: Nannen-Verlag, 1965.

Diederich, Victor. Internationale Einrichtungen: Kursus für die Sekunda der Mittelschulen. Luxembourg: MEN, 1973.

Diederich, Victor, and Marcel Ditsch. Sozialkunde: Handbuch für die Komplementarklassen (8. Schuljahr) des Grossherzogtums Luxemburg. Luxembourg: MEN, 1973.

École et vie. "Die Komplementarklassen im Gespräch." In École et vie 3, 62-76. Luxembourg: Syndicat national des enseignants, 1975. 
Eduskunta. Hallituksen Esitys Eduskunnalle Laiksi Koulujärjestelmän Perusteista: He44/1967. Helsinki: Valtion Painatuskeskus: asetuskokoelma 467, 1968.

Englund, Tomas. "Education as a citizenship right-a concept in transition: Sweden related to other Western democracies and political philosophy." Journal of Curriculum Studies 26, no. 4 (1994), 383-99.

Esping-Andersen, Gøsta. The Three Worlds of Welfare Capitalism. Princeton: Princeton University Press, 1990.

European Commission. "Non-national population by group of citizenship and foreign-born population by country of birth." European Commission (Eurostat). http://ec.europa.eu/eurostat/statistics/explained/index.php/File:Non_national_population_by_group_of_citizens_andforeignborn_population_by_country_of_birth,_1_January_2013_YB14_II.png. (accessed September 20, 2015).

Flora, Peter, and Jens Alber. "Modernization, Democratization, and the Development of Welfare States in Western Europe." In The Development of Welfare States in Europe and America, edited by Peter Flora and Arnold Heidenheimer, 37-80. London: Transaction Books, 1981.

Fuchs, Eckhardt, and Marcus Otto. "Introduction: Educational Media, Textbooks, and Postcolonial Relocations of Memory Politics." Journal of Educational Media, Memory, and Society 5, no. 1, Special Issue: Europe in Postcolonial Politics of Memory in Educational Media (2013), 1-13.

Gardin, Matias. "States of education: reflections on the relationship between welfare state and education in Finland and the Federal Republic of Germany 1960-1970." PhD diss., King's College London, 2013.

Gardin, Matias. "Globalization in Finnish and West German Educational Rhetoric, 19601970." In Trajectories in the Development of Modern School Systems: Between the National and the Global, edited by Daniel Tröhler and Thomas Lenz, 183-96. New York: Routledge, 2015.

Gardin, Matias and Ingrid Brühwiler. "Fabricating National Unity in Torn Contexts: World War I in the Multilingual Countries of Switzerland and Luxembourg." In Small Nations and Colonial Peripheries in World War I, edited by Gearóid Barry, Enrico Dal Lago, and Róisín Healy, 140-56. Leiden: Brill, 2016.

Giroux, Henry, and David Purpel. The Hidden Curriculum and Moral Education: Deception or Discovery?. Berkeley: McCutchan, 1983.

Goffin, Séverine. "Lorientation des élèves changera dès 2016." L'essentiel. http:// www.lessentiel.lu/fr/news/story/18931211 (accessed September 20, 2015).

Goodson, Ivor. The Making of the Curriculum: Collected Essays. Washington DC/ London: Falmer Press, 1988.

Graf, Lukas, and Daniel Tröhler. "Berufsausbildung in Luxemburg: historische Ursprünge, institutionelle Struktur und aktuelle Herausforderungen.” In Bildungsbericht Luxemburg 2015 - Band 2 : Analysen und Befunde, edited by Thomas Lenz, Andreas Hadjar, Adelheid Hu, Romain Martin, Christine Schiltz and Daniel Tröhler, 103-8. Luxembourg: MENJE, 2015.

Hague, Rod, and Martin Harrop. Comparative Government and Politics. London: Macmillan Education, 2013.

Hahn, Carole. Becoming Political: Comparative Perspectives on Citizenship Education. Albany: State University of New York Press, 1998. 
Huovinen, Pentti. Kuka kukin on 1978: Henkilötietoja nykypolven suomalaisista. Helsinki: Otava, 1978.

Huttunen, Veikko, and Kai Lehtonen. Yhteiskuntaoppi. Helsinki: WSOY, 1970.

Jaans, Jean, Pierre Kirchen, Marcel Spielmann, and Jacques Wathgen. Lehrbuch der Bürgerkunde: Für die technischen und beruflichen Lehranstalten. Esch-sur-Alzette: Genossenschaftsdruckerei, 1970.

Kettunen, Pauli. "The Nordic Welfare State in Finland." Scandinavian Journal of History 26, no. 3 (2001), 225-47.

Lenz, Thomas, Anne Rohstock, and Catherina Schreiber. "Tomorrow Never Dies: A Socio-Historical Analysis of the Luxembourgish Curriculum." In International Handbook of Curriculum Research, edited by William Pinar, 315-28. New York: Routledge, 2013.

Meinander, Ragnar. Suomalainen yhteiskuntamme. Helsinki: Otava, 1967.

MENJE. Les chiffres clés de l'Éducation nationale. Statistiques et indicateurs 20122013. Luxembourg: MENJE, 2014.

OECD. PISA 2012 Results: What Students Know and Can Do. Paris: OECD publications, 2014.

OECD. OECD Economic Surveys Luxembourg. Paris: OECD publications, 2015.

OECD. "Education at a Glance 2013: Country note for Finland." OECD. http://www. oecd.org/edu/Finland_EAG2013\%20Country\%20Note.pdf (accessed September 20, 2015).

OECD. "Teachers' salaries. Annual statutory salaries in public institutions." OECD. http://www.oecd-ilibrary.org/education/teachers-salaries-2013-1_teachsal-table-2013-1-en (accessed September 20, 2015).

OECD. "Education at a Glance 2013: Country note for Luxembourg." OECD. http:// www.oecd.org/edu/Luxembourg_EAG2013\%20Country\%20Note.pdf (accessed September 25, 2015).

Pekkala Kerr, Sari. "Koulutusmenot ja väestön koulutustaso." In Tiedon ja osaamisen Suomi. Kasvatus ja koulutus Suomessa 1960-luvulta 2000-luvulle, edited by Pauli Kettunen and Hannu Simola, 295-320. Hämeenlinna: Karisto, 2012.

Przeworski, Adam, and Henry Teune. The Logic of Comparative Social Inquiry. New York: Wiley Interscience, 1970.

Putnam, Robert. "Bowling Alone: America’s Declining Social Capital." Journal of Democracy 6, no. 1 (1995), 65-78.

Reid, Alan, Judith Gill, and Alan Sears. eds., Globalization, the Nation-State and the Citizen: Dilemmas and Directions for Civics and Citizenship Education. New York: Routledge, 2010.

Reiff, Paul. "Lévolution de l'enseignement depuis 1960." STATEC. http://www.statistiques.public.lu/fr/publications/series/luxembourg/2012/14-12/index.html (accessed July 1, 2015).

Rinne, Risto. "From ethos to habitus: the changing curriculum codes of Finnish Schooling, 1881-1985." Journal of Curriculum Studies 20, no. 5 (1988), 423-35.

Sahlberg, Pasi. "Education Reform for Raising Economic Competitiveness." Journal of Educational Change 7, no. 4 (2006), 259-87.

Schreiber, Catherina. "Curricula and the Construction of Citizens. An analysis of the Luxembourgian Curriculum in the 19th and 20th centuries." PhD diss., University of Luxembourg, 2014. 
Thoma, Emile. Le livre scolaire luxembourgeois à travers les âges. Luxembourg: Bibliothèque nationale, 1980.

Torney-Purta, Judith, Rainer Lehmann, Hans Oswald, and Wolfram Schulz. eds., Citizenship and Education in Twenty-eight Countries: Civic Knowledge and Engagement at Age Fourteen. Amsterdam: IEA, 2001.

Torsti, Pilvi. Suomalaiset ja historia. Helsinki: Gaudeamus, 2012.

Tröhler, Daniel. "Citizenship and education in a plural world.” Education Letter 9, no. 2 (2014), 15-7.

Valtavaara, Marjo. "Lukioon entistä vaikeampi päästä - ylioppilaiden määrä on romahtanut.” Helsingin Sanomat. http://www.hs.fi/kotimaa/a1418970101442 (accessed September 20, 2015).

Vilkko, Marjo. Suomi on ruotsalainen. Helsinki: Schildts \& Söderströms, 2014

Welzel, Christian, and Ronald Inglehart. "Political Culture." In Comparative Politics, edited by Daniele Caramani, 311-30. Oxford: Oxford University Press, 2011.

West, Anne, and Rita Nikolai. "Welfare Regimes and Education Regimes: Equality of Opportunity and Expenditure in the EU (and US)." Journal of Social Policy 42, no. 3 (2013), 474-6.

Winch, Christopher. "Vocational and Civic Education: Whither British Policy?" Journal of Philosophy of Education 46, no. 4 (2012), 603-18. 